\title{
Uroczystość Odnowienia Doktoratu Profesor Kamilli Mrozowskiej
}

Wśród uroczystości jubileuszowych szczególny wymiar mają te, które poświęcone sq̨ wybitnym jednostkom $\mathrm{i}$ ich udziałowi w rozwoju nauki i kultury. Wówczas mamy do czynienia ze swoistą formą spotkania. Jest to bowiem spotkanie $\mathrm{z}$ kimś $\mathrm{i}$ czymś: $\mathrm{z}$ osobą, przeszłością, wiedzą i mądrością, wynikającą z doświadczenia.

Właśnie taka uroczystość została zorganizowana przez Dziekana i Radę Wydziału Historycznego Uniwersytetu Jagiellońskiego dla uczczenia Odnowienia Doktoratu Pani Profesor Kamilli Mrozowskiej, wybitnej polskiej uczonej z zakresu historii wychowania, szkolnictwa i nauki. Spotkanie odbyło się 29 października 1998 roku w Auli Collegium Maius Uniwersytetu Jagiellońskiego. Po oficjalnym otwarciu uroczystości przez władze uczelni w osobie Rektora Prof. dr hab. A. Koja, glos zabrał Prof. dr hab. Julian Dybiec, promotor jubileuszu, który przedstawił osobę Jubilatki, Jej główne kierunki badań $\mathrm{i}$ wkład w rozwój nauki polskiej. W swoim przemówieniu, podkreślił także udział Pani Profesor w pracach organizacyjnych nad rozwojem badań naukowych oraz Jej działania i troskę o miejsce i znaczenie historii wychowania wśród nauk humanistycznych. Zaznaczył przy tym, iż Prolesor K. Mrozowska w swojej działalności kierowała się postawą prawđziwego nauczyciela i mistrza.

Najdonioślejszym momentem uroczystości było przemówienie samej Jubilatki, mające walory wykładu naukowego a zarazem wspomnienia: osób, wydarzeń, które miały wpływ na przebieg Jej życia i kariery naukowej. Wśród wielu osób, które zaznaczyły swój udział w życiu Pani Profesor, szczególne miejsce przypadło Jej matce, Halinie Mrozowskiej, która wprowadziła swoją córkę w tajniki pracy nauczycielskiej, naukowej i działalności społeczno-oświatowej. Natomiast wśród mistrzów nauki niewątpliwa rolę odegrał m. in. M. Handelsman, z którego szkoły wyszła. Mówiąc, zaś o swoich zainteresowaniach naukowych, Profesor K. Mrozowska uzasadniała dlaczego z upodobaniem zajmowała się glównie Oświeceniem, dlaczego tak wiele miejsca w swojej twórczości naukowej poświęciła zagadnieniom KEN i sprawom oświaty i nauki w Oświeceniu. Niewątpliwie, jak można było wywnioskować z Jej słów, przyczyną zainteresowań tym okresem była fascynacja ideami oświeceniowymi, a kantowskie stwierdzenie „miejcie odwagę posługiwać się własnym rozumem" stało się mottem w Jej twórczości naukowej, pracy pedagogicznej i całym życiu. W zakończeniu swojego wystąpienia podkreśliła, iż wiele idei tamtych czasów należałoby odnieść do współczesności, nade wszystko odpowiednie pojmowanie relacji „należność i powinność", tak jak ją ujmowali nauczyciele czasów Komisji Edukacji Narodowej. Ideały przyświecające nauczycielom z czasów KEN były jej szczególnie drogie, gdyż sama w swojej działalności wyszła od pracy nauczycielskiej, którą kochała, i w której, jak stwierdziła, „dobrze się czuła” przechodząc następnie do pracy naukowej. Dlatego też zawód nauczycielski traktowała jako służbę dla kształtowania systemu wartości intelektualnych, moralnych i estetycznych, które uważała za podstawę oświaty i nauki polskiej.

Całe wystąpienie nacechowane było ogromną wiedzą, mąđrością życiową, a przede wszystkim wielką pokorq wobec siebie samej i własnych dokonań. Nie było tam słów, mówiących o wielkich czynach, czy osiągnięciach, a przecież Jubilatce przyszło żyć w bardzo trudnych momentach historii Polski. Co więcej nie było słów oskarżenia pod adresem czegokolwiek, czy kogokolwiek, lecz słowa świadczące o tolerancji i mimo wszystko o optymizmie.

W tej pięknej uroczystości uczestniczyli przedstawiciele historii, historii wychowania i pedagogiki większości ośrodków naukowych kraju. Swój szacunek przybyli wyrazić jej uczniowie i współpracownicy, a także ci którzy mieli przyjemność poznania Pani Profesor w Jej różnorodnej działalności.

Wadyslawa Szulakiewicz 